\title{
DEVELOPMENT OF A RUBRIC FOR THE EVALUATION OF “DESIGN AND PROJECT" COMPETENCE IN AN EXPERIMENTAL SUBJECT OF CHEMICAL ENGINEERING DEGREE
}

\author{
M. Sancho, B. García-Fayos, J.M. Arnal \\ Chemical and Nuclear Eng. Department, Universitat Politècnica de València (SPAIN)
}

\begin{abstract}
"Experimentation in Chemical Engineering III" is the last experimental core course of the Chemical Engineering Degree at the Universitat Politècnica València (UPV). It is a practical course of 4.5 ECTS which is taught in the 2nd semester of the 3rd year, in which students perform experimental sessions related to the subject "Separation Processes" taught in the previous semester. The subject has to work the competence "Design and Project", both in its specific and transversal approach. In order to develop suitably such competence, in 2016 it was requested an "Innovation and Education Improvement Project" (PIME), through the Institute of Education Sciences of the UPV, with the aim of integrate the Project Oriented Learning (POL) as the main methodology. The Project was implemented during the academic year 2017-2018 and the main objective was to perform experimental sessions to obtain data that would be used in the design project.
\end{abstract}

Transition to POL methodology implied the design and development of new activities [1] and a change in the way that the evaluation was performed. The design project was the main learning product obtained and it is used to assess the development of the "Design and project" competence in the students. The tool used to evaluate the design project is a rubric. Rubric includes the evaluation criteria and their different levels of achievement and scoring, and allows a more homogeneous assessment by all the lecturers that evaluate the project.

This paper describes the development process of the rubric and presents the final version which is currently used in the subject after two years of implementation that includes several changes made. This work will also describe the way that score of each item contributes to the final grade of the project and of the competence. The rubric presented can be applied to other subjects in which similar design projects would be performed, after adapting it to the particular context of each subject.

Keywords: Design, project, Project Oriented Learning, evaluation, rubric.

\section{INTRODUCTION}

\subsection{Subject context}

The object of this work is the subject "Experimentation in Chemical Engineering III", the last of a group of core experimental subjects of the Chemical Engineering Degree from the Universitat Politècnica Valencia (UPV). It is a practical course of 4,5 ECTS credits taught in the $2^{\text {nd }}$ semester of third course in which students perform experimental sessions related to the subjects "Separation Operations" and "Chemical Reactors", both taught in the first semester of the said course. The subject must develop the competence "Design and project", both in its specific and transversal approach. In order to work suitably such competence, in 2016 an Innovation and Education Improvement Project (PIME), approved by the Institute of Education Sciences of the UPV, was implemented for the integration of the Project Oriented Learning (POL) as the main methodology of the subject [1]. This methodology was chosen because it has been proposed by several studies as a method that integrates selflearning, knowledge, problem solving and creativity methodology, which makes it very suitable for the learning of engineering [2]. In addition, it has been shown that it facilitates the development of engineering type thinking and it also increases students' motivation towards learning [3]. On the other hand, this methodology implies the work in groups and the development of practices similar to those of the professional world, which complements the training of students in a very positive way.

The subject "Experimentation in Chemical Engineering III ", in which the POL methodology has been integrated, is divided into two teaching units. The first one consists of laboratory sessions about the core subjects of chemical engineering taught in the first semester of the third year. The second unit consists of simulation computer sessions. Of the total of 12 teaching weeks, 8 of them are dedicated 
to the experimental unit and the remaining 4 weeks to the teaching unit of simulation. The methodology of learning by projects was implemented in the experimental part of the subject. To do so, a common thread for experimental sessions was established, which consists in the process of oil production from seeds. Thus, laboratory sessions were designed so that each one of them corresponds with a part of the industrial process or is related to any discipline to be implemented in the subsequent design of the process. The experimental sessions that are performed, in chronological order, are the following:

- Safety and health

- Crushing and sieving of the raw material

- Solid-liquid extraction of the seed oil

- Recovery of the solvent by differential distillation

- Identification of plastics by means of simple tests

- Valorization of wastes

Besides these 6 experimental sessions, 2 remaining weeks are dedicated to the tutoring of the project and to its oral defense.

Regarding the way of developing the experimental unit, students work in the lab sessions those concepts related to the process to design, and they must write and deliver a report at the end of each session, which is then corrected by the teacher and returned as soon as possible to provide feedback for the development of the project. These reports of experimental sessions constitute the "Academic work" of the subject, and they are included in the evaluation in a way that will be showed later. On the other hand, the project basically consists in the design of an industrial extractor as well as the main stages and elements of the full industrial process, which have to be graphically represented in a block diagram and in a flow one. Finally, the project is delivered as a writing report and it is also orally defended against teachers and students. All these aspects are covered in the evaluation of the subject, as it is described in the next section.

\subsection{POL evaluation}

One of the important aspects for the success of this type of active methodologies is that evaluation must be consistent with the activities carried out and, effectively, promote active learning through a formative evaluation.

Usually, the evaluation of the POL is done via written work and oral presentations, at various times throughout the development of the project to ensure a formative evaluation [4]. Therefore, the change of methodology in the subject "Experimentation in Chemical Engineering III" also involved changes in the system of evaluation, which has been established in the following way [1]:

- Academic work $(20 \%)$. It consists of the marks obtained in the reports for each experimental session, which are returned corrected to the students approximately within 1-2 weeks to provide the necessary feedback for the adequate development of the project.

- Project (30\%). It consists of the written report of design presented by each group of students at the end of the experimental teaching unit.

- Oral exam (10\%). It consists of the oral defense of the project by each group of students against the group of teachers and the rest of students.

- Written exam (40\%). Within this percentage, $10 \%$ corresponds to questions about the theoretical content of the experimental unit, and the remaining $30 \%$ corresponds to the teaching unit of simulation.

To deal with the evaluation of the project, it has been decided to use a rubric, one of the evaluation tools that is gaining increasing interest for the reliably evaluation of complex skills, as the addressed by the methodology of Project Oriented Learning [5]. It is a particularly useful tool to guide evaluation processes and generate quality information about teaching results. Among its numerous benefits they can be emphasized [6]:

- It facilitates the achievement of learning objectives thanks to the transparency that the evaluation criteria show.

- If it becomes public at the beginning, it favors a significant student learning. 
- It can be used as an evidence of the performance of students.

- It provides feedback on the assessment of the work of the student and feedforward on what to do to improve this assessment.

- It increases the motivation and involvement of students towards the task to perform.

- It focuses the lecturers in their practice and can be an aid for the achievement of teaching objectives, besides giving information about the development of the learning of students which would allow reviewing the teaching practice and taking appropriate measures.

- It promotes practices of self-assessment and peer review, which gives students autonomy and responsibility for their own learning.

Thus, rubrics are resources which have great educational potential, which allow not only the evaluation of competences, but generate processes that enable their development. Therefore, they are being used increasingly to a greater extent in higher education in a wide variety of disciplines and for the qualification of a variety of products that include projects [7]. These tools seem to be especially useful when there are different evaluators for a same task or product, since it allows reaching greater consistency in the proposed qualifications than with other evaluation tools [5].

Therefore, in the subject object of this work it has been developed a rubric to assess the competence "Design and project", as it is described in the following sections. The rubric will be showed and it will be described the application of the rubric in the last two academic years to obtain the qualification of the Project in the final grade of the course, as well as for the evaluation of the corresponding transversal competence.

\section{METHODOLOGY}

This section describes the methodology followed for the elaboration and implementation of a rubric for the evaluation of the competence "Design and project".

\subsection{Rubric elaboration}

Rubrics are composed of three elements:

1 Evaluation criteria. What is considered important in assessing, i.e. the different dimensions to consider to determine the degree of quality of a work.

2 Quality definitions. They are sentences that detail and explain the degree of quality of the achievement of a certain criterion.

3 Levels of achievement. They are the different levels of achievement of the criteria which, usually, are organized in ascending way.

It must be borne in mind that, once made the rubric, this is a flexible element that can and should be modified for improvement, so it will be reviewable for its better implementation.

For the development of the rubric object of this work, we have followed the following steps:

a) Definition of learning results or outcomes. Specification of what should a student really know to do and have produced after the evaluated activity. Knowledge, skills and attitudes which the student should have acquired.

b) Identification of dimensions or aspects to evaluate. Qualities of the activity which show optimal performance of the learning outcomes. These aspects are organized into categories or dimensions.

c) Establishment of the rating scale, i.e. how many levels of every aspect will be defined (normally 3 to 5 ).

d) Writing of the descriptors of each level for each evaluated aspect, which should be based on directly observable characteristics. 


\subsection{Application of the rubric}

Once the rubric was developed, it has been implemented in the last two academic years (2016/172017/18) for the evaluation of the Project of the subject "Experimentation in Chemical Engineering III", as well as the transversal competence "Design and project" assigned to that course. To do this, the lecturers of the subject applied the rubric for the correction of the Project of each group of students, by selecting the appropriate level for each evaluated dimension. After this, assessments of all dimensions were transformed into a numerical rating, to incorporate it into the overall evaluation of the subject, and they were also turned into an alphabetical evaluation of the transversal competence. Criteria for transformation of the results of the rubric in both evaluations are described in the next section, where the results of application of the rubric in the last two academic years are discussed.

\section{RESULTS}

In this section it is presented, on the one hand, the rubric developed and, on the other hand, the results obtained after the application of it in the last two academic years.

\subsection{Description of the rubric}

The description of the rubric elaboration follows the stages defined in the methodology section of this work.

\section{A. Definition of learning outcomes}

Competences related to design of the subject "Experimentation in Chemical Engineering III" are the following:

- Specific competence: Designing processes in different industrial activities in the field of chemical engineering

- Transversal competence: Design and project, whose development is focused on students' learning by making and integrating knowledge and skills in multidisciplinary areas.

The learning results (LR) or outcomes that allow analyzing the level of acquisition of these competencies are outlined below:

- LR1.Define and describe the stages that make up the seed oil production process

- LR2.Draw the block diagram of the production process according to the standard UNE 10628

- LR3. Understand the UNE standard about graphical representation of processes

- LR4.Select the industrial equipment that can be used to carry out the production process of interest

- LR5.Implement and explain the necessary safety measures in the industrial installation

- LR6.Design and represent the solid-liquid extraction process to operate in a continuous way

- LR7.Identify the waste generated in the process and suggest alternatives for their valorization

- LR8.Adequacy of the written report

- LR9.Implication and cooperation of all members of the group

\section{B. Identification of dimensions or aspects to evaluate}

Dimensions identified for each learning outcome are those shown in Table 1, along with learning results (LR) to which they correspond.

The three dimensions that appear shaded in Table 1 correspond to the ones that make up the design block, whose valuation will differ from that of the rest of descriptors in the transformation criteria described in sections 3.2.1 and 3.2.2. 
Table 1. Dimensions to evaluate learning result.

\begin{tabular}{|l|c|}
\hline \multicolumn{1}{|c|}{ Dimensions } & Learning Result \\
\hline Definition of objectives appropriate to the scope of the project & LR8 \\
\hline Proposal of industrial equipment for each stage of the process & LR1 / LR2 / LR4 \\
\hline $\begin{array}{l}\text { Interpretation of the link of each practice with the design of the } \\
\text { installation }\end{array}$ & LR6 \\
\hline $\begin{array}{l}\text { Characteristics of the design in accordance with the experimental } \\
\text { development at the laboratory }\end{array}$ & LR3 / LR4 \\
\hline Integration of the constructive elements in the design of the installation & LR6 \\
\hline Creativity of the design & LR5 \\
\hline Adequacy of the installation to the identified risks & LR7 \\
\hline Methodology for the valorization of wastes & LR8 \\
\hline References & LR8 \\
\hline Format of the written project & LR9 \\
\hline Cohesion and participation of the members of the group & \\
\hline
\end{tabular}

\section{Establishment of the rating scale (levels)}

For each dimension, 4 skill levels have been established: $A, B, C$ and $D$, which correspond to criteria and descriptions shown in Table 2.

Table 2. Rubric rating scale (levels).

\begin{tabular}{|c|c|l|}
\hline Level & Assessment & \multicolumn{1}{c|}{ Description } \\
\hline A & Excellent & The competence is greatly exceeded \\
\hline B & Good/appropriate & The competence is completely reached \\
\hline C & Under development & The competence is not reached, i.e. the approach fails the minimum level. \\
\hline D & Not reached & Do not have sufficient evidence to assess it \\
\hline
\end{tabular}

\section{Writing the descriptors of each level}

Finally, each descriptor corresponding to each level of qualifications within each dimension is written, finalizing the rubric of evaluation that can be observed in Table 3.

Table 3. Rubric for the evaluation of competence "Design and project" in the subject "Experimentation in Chemical Engineering III" of Chemical Engineering Degree of the UPV.

\begin{tabular}{|c|c|c|c|c|}
\hline \multirow[b]{2}{*}{ DIMENSIONS } & \multicolumn{4}{|c|}{ DESCRIPTORS } \\
\hline & D. Not reached & $\begin{array}{c}\text { C. Under } \\
\text { development }\end{array}$ & $\begin{array}{l}\text { B. Good / } \\
\text { Appropriate }\end{array}$ & A. Excellent \\
\hline $\begin{array}{l}\text { Definition of } \\
\text { objectives } \\
\text { appropriate to } \\
\text { the scope of } \\
\text { the project }\end{array}$ & $\begin{array}{l}\text { The objectives do } \\
\text { not correspond to } \\
\text { the scope of the } \\
\text { project }\end{array}$ & $\begin{array}{l}\text { The objectives are } \\
\text { coherent but do not } \\
\text { cover the scope of the } \\
\text { project }\end{array}$ & $\begin{array}{l}\text { The objectives are } \\
\text { coherent and attend } \\
\text { the scope of the } \\
\text { project }\end{array}$ & $\begin{array}{l}\text { The objectives are } \\
\text { appropriate and } \\
\text { completely cover } \\
\text { the scope of the } \\
\text { project }\end{array}$ \\
\hline $\begin{array}{l}\text { Proposal of } \\
\text { industrial } \\
\text { equipment for } \\
\text { each stage of } \\
\text { the process }\end{array}$ & $\begin{array}{l}\text { Most of the } \\
\text { proposed industrial } \\
\text { equipment is not } \\
\text { suitable. }\end{array}$ & $\begin{array}{l}\text { Some proposed } \\
\text { industrial equipment is } \\
\text { suitable. }\end{array}$ & $\begin{array}{l}\text { Most of the } \\
\text { proposed industrial } \\
\text { equipment is } \\
\text { suitable. }\end{array}$ & $\begin{array}{l}\text { All proposed } \\
\text { industrial equipment } \\
\text { is suitable. }\end{array}$ \\
\hline
\end{tabular}




\begin{tabular}{|c|c|c|c|c|}
\hline $\begin{array}{l}\text { Interpretation of } \\
\text { the link of each } \\
\text { practice with } \\
\text { the design of } \\
\text { the installation }\end{array}$ & $\begin{array}{l}\text { Link of lab and } \\
\text { design is not } \\
\text { correct and/or } \\
\text { incomplete for most } \\
\text { experimental } \\
\text { sessions }\end{array}$ & $\begin{array}{l}\text { Link of lab and design } \\
\text { is correct and } \\
\text { complete only for } \\
\text { some experimental } \\
\text { sessions }\end{array}$ & $\begin{array}{l}\text { Link of lab and } \\
\text { design is correct } \\
\text { and complete for } \\
\text { most experimental } \\
\text { sessions }\end{array}$ & $\begin{array}{l}\text { Link of lab and } \\
\text { design is correct } \\
\text { and complete for all } \\
\text { the experimental } \\
\text { sessions }\end{array}$ \\
\hline $\begin{array}{l}\text { Characteristics } \\
\text { of the design in } \\
\text { accordance } \\
\text { with the } \\
\text { experimental } \\
\text { development at } \\
\text { the laboratory }\end{array}$ & $\begin{array}{l}\text { Design does not } \\
\text { match experimental } \\
\text { characteristics }\end{array}$ & $\begin{array}{l}\text { Design match some of } \\
\text { the experimental } \\
\text { characteristics }\end{array}$ & $\begin{array}{l}\text { Design match most } \\
\text { of the experimental } \\
\text { characteristics }\end{array}$ & $\begin{array}{l}\text { Design match all the } \\
\text { experimental } \\
\text { characteristics }\end{array}$ \\
\hline $\begin{array}{l}\text { Integration of } \\
\text { the constructive } \\
\text { elements in the } \\
\text { design of the } \\
\text { installation }\end{array}$ & $\begin{array}{l}\text { There is a lack of } \\
\text { many constructive } \\
\text { elements in the } \\
\text { design }\end{array}$ & $\begin{array}{l}\text { There is a lack of } \\
\text { some constructive } \\
\text { elements in the design }\end{array}$ & $\begin{array}{l}\text { The design } \\
\text { integrates most of } \\
\text { the constructive } \\
\text { elements }\end{array}$ & $\begin{array}{l}\text { The design } \\
\text { integrates all the } \\
\text { constructive } \\
\text { elements }\end{array}$ \\
\hline $\begin{array}{l}\text { Creativity of the } \\
\text { design }\end{array}$ & $\begin{array}{l}\text { The level of } \\
\text { creativity is very } \\
\text { low or non-existing }\end{array}$ & $\begin{array}{l}\text { The level of creativity } \\
\text { is low }\end{array}$ & $\begin{array}{l}\text { The level of } \\
\text { creativity is quite } \\
\text { high }\end{array}$ & $\begin{array}{l}\text { The level of } \\
\text { creativity is very } \\
\text { high }\end{array}$ \\
\hline $\begin{array}{l}\text { Adequacy of } \\
\text { the installation } \\
\text { to the identified } \\
\text { risks }\end{array}$ & $\begin{array}{l}\text { The design does } \\
\text { not considers any } \\
\text { of the identified } \\
\text { risks }\end{array}$ & $\begin{array}{l}\text { The design considers } \\
\text { some of the identified } \\
\text { risks }\end{array}$ & $\begin{array}{l}\text { The design } \\
\text { considers most of } \\
\text { the identified risks }\end{array}$ & $\begin{array}{l}\text { The design } \\
\text { considers all the } \\
\text { identified risks }\end{array}$ \\
\hline $\begin{array}{l}\text { Methodology } \\
\text { for the } \\
\text { valorization of } \\
\text { wastes }\end{array}$ & $\begin{array}{l}\text { There is a lack of } \\
\text { valorization } \\
\text { methodology }\end{array}$ & $\begin{array}{l}\text { The valorization } \\
\text { methodology is } \\
\text { incomplete and/or } \\
\text { incorrect }\end{array}$ & $\begin{array}{l}\text { The valorization } \\
\text { methodology is } \\
\text { suitable but } \\
\text { incomplete }\end{array}$ & $\begin{array}{l}\text { The valorization } \\
\text { methodology is } \\
\text { suitable and } \\
\text { complete }\end{array}$ \\
\hline References & $\begin{array}{l}\text { Most references } \\
\text { are not suitable } \\
\text { and/or not well } \\
\text { indicated }\end{array}$ & $\begin{array}{l}\text { Only some references } \\
\text { are suitable and well } \\
\text { indicated }\end{array}$ & $\begin{array}{l}\text { Most references are } \\
\text { suitable and well } \\
\text { indicated }\end{array}$ & $\begin{array}{l}\text { All the references } \\
\text { are suitable and well } \\
\text { indicated }\end{array}$ \\
\hline $\begin{array}{l}\text { Format of the } \\
\text { written project }\end{array}$ & $\begin{array}{l}\text { The Project does } \\
\text { not follow the } \\
\text { guidelines about } \\
\text { format }\end{array}$ & & & $\begin{array}{l}\text { The Project follows } \\
\text { the guidelines about } \\
\text { format }\end{array}$ \\
\hline $\begin{array}{l}\text { Cohesion and } \\
\text { participation of } \\
\text { the members of } \\
\text { the group }\end{array}$ & $\begin{array}{l}\text { There has been no } \\
\text { cohesion between } \\
\text { the members of the } \\
\text { group, and they } \\
\text { participated very } \\
\text { unevenly }\end{array}$ & $\begin{array}{l}\text { There has been no } \\
\text { cohesion between the } \\
\text { members of the group, } \\
\text { but the participation } \\
\text { has been pretty fair }\end{array}$ & $\begin{array}{l}\text { Cohesion and group } \\
\text { participation has } \\
\text { been high and } \\
\text { equitable }\end{array}$ & $\begin{array}{l}\text { Cohesion and group } \\
\text { participation has } \\
\text { been very high and } \\
\text { completely equitable }\end{array}$ \\
\hline
\end{tabular}

\subsection{Results of rubric application}

This section shows the results of implementation of the rubric to obtain the numerical rating of the Project as well as to obtain alphabetical assessment of the transversal competence "Design and project".

\subsubsection{Application of the rubric for Project evaluation}

\section{A. Criteria for transforming the results of the rubric into the mark of the Project}

Table 4 shows the criteria defined to transform alphabetical assessment obtained by the rubric, corresponding to different levels, into the numerical rating of the Project. For each numerical rating it is indicated if it can be (YES) or not (NO) assessments of each level, showing also in some cases the number of such assessment that is considered appropriate for the qualification. 
Table 4. Criteria for transforming results of the rubric into the mark of the Project.

\begin{tabular}{|c|c|c|c|c|c|c|c|c|}
\hline \multirow[t]{2}{*}{ Mark } & \multicolumn{4}{|c|}{ Assessment descriptors DESIGN block } & \multicolumn{4}{|c|}{ Assessment of the rest of descriptors } \\
\hline & A & B & C & D & A & B & C & D \\
\hline 10 & All & NO & NO & NO & Majority & $1-2$ & NO & NO \\
\hline 9,5 & Majority & 1 & NO & NO & Majority & YES & NO & NO \\
\hline \multirow{2}{*}{9,0} & Majority & 1 & NO & NO & YES & Majority & NO & NO \\
\hline & Majority & 1 & NO & NO & Majority & YES & 1 & NO \\
\hline \multirow{2}{*}{$8,5-8,75$} & YES & Majority & NO & NO & YES & YES & NO & NO \\
\hline & All & NO & NO & NO & YES & YES & $1-2$ & NO \\
\hline \multirow{2}{*}{$8,0-8,25$} & YES & Majority & NO & NO & YES & YES & 3 & NO \\
\hline & All & NO & NO & NO & YES & YES & 3 & NO \\
\hline 7,75 & YES & YES & 1 & NO & YES & YES & YES $(<3)$ & NO \\
\hline 7,5 & YES & YES & 1 & NO & YES & YES & YES $(\geq 3)$ & NO \\
\hline 7,0 & YES & YES & 1 & NO & YES & YES & YES & 1 \\
\hline 6,5 & YES & YES & NO & SI & YES & YES & YES & NO \\
\hline 6,0 & YES & YES & NO & SI & YES & YES & YES & $1-2$ \\
\hline 5,0 & YES & YES & NO & SI & YES & YES & Majority & YES \\
\hline \multirow{2}{*}{$<5,0$} & YES & YES & YES & $\geq 2$ & YES & YES & YES & YES \\
\hline & YES & YES & YES & 1 & YES & YES & YES & Majority \\
\hline
\end{tabular}

\section{B. Results of Project evaluation in two last academic years}

The criteria shown in Table 4 have been applied in the last two years to obtain the marks of the projects carried out by students. Figure 1 shows the percentage of each range of rating obtained in such academic years.

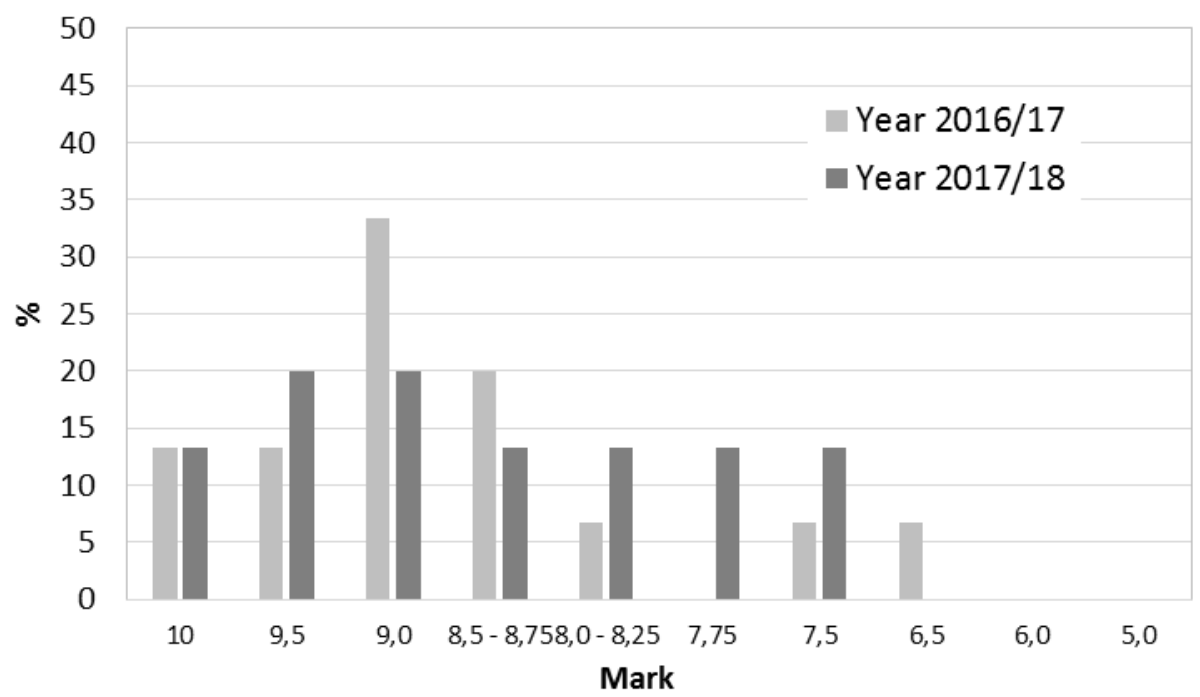

Figure 1. Results of Project evaluation by the rubric.

As it is shown in the figure, there was a high percentage of marks higher than 9: $60 \%$ in year 2016/17 and $46,7 \%$ in year $2017 / 18$. There has been only a mark below 7 in one of the years, specifically 6,5 in 2016/17. There have not been marks below this in any of the two academic years. According to these 
results, it seems that marks obtained by the application of the rubric are consistent with the excellent results obtained with the application of the methodology of Project Oriented Learning in experimental contexts [8].

With respect to the advantages observed by lecturers regarding the use of the rubric, it should be highlighted the ease of evaluation thanks to having criteria clearly defined via descriptors, which significantly reduces the time spent on the evaluation of the project.

On the other hand, the greatest difficulty has been precisely the writing of the descriptors, which had to be modified during the implementation of the rubric to fit better to what we really wanted to evaluate. It should be noted that to get a reliable rubric it is essential to undergo a process of review by other teachers, as well as establish a continuous feedback between these during rubric application.

\subsubsection{Application of the rubric for the evaluation of the transversal competence}

A. Criteria for transforming the results of the rubric into the assessment of the transversal competence

Table 5 shows the defined criteria to transform the alphabetical result obtained by the rubric in the final assessment of the transversal competence "Design and project".

Table 5. Criteria for transforming results of the rubric into the assessment of the transversal competence.

\begin{tabular}{|c|l|}
\hline Assessment & \multicolumn{1}{c|}{ Criteria } \\
\hline A & Provided that there is no D in any relevant part of the design \\
\hline B & If there is 1 D in any relevant part of the design \\
\hline C & If there are 2 D's in the design \\
\hline D & If there are most of D in the design \\
\hline
\end{tabular}

\section{B. Results of transversal competence evaluation in two last academic years}

The criteria shown in Table 5 have been applied in the last two years to obtain assessment of the transversal competence "Design and project". Figure 2 shows the percentage of each assessment obtained in such academic years.

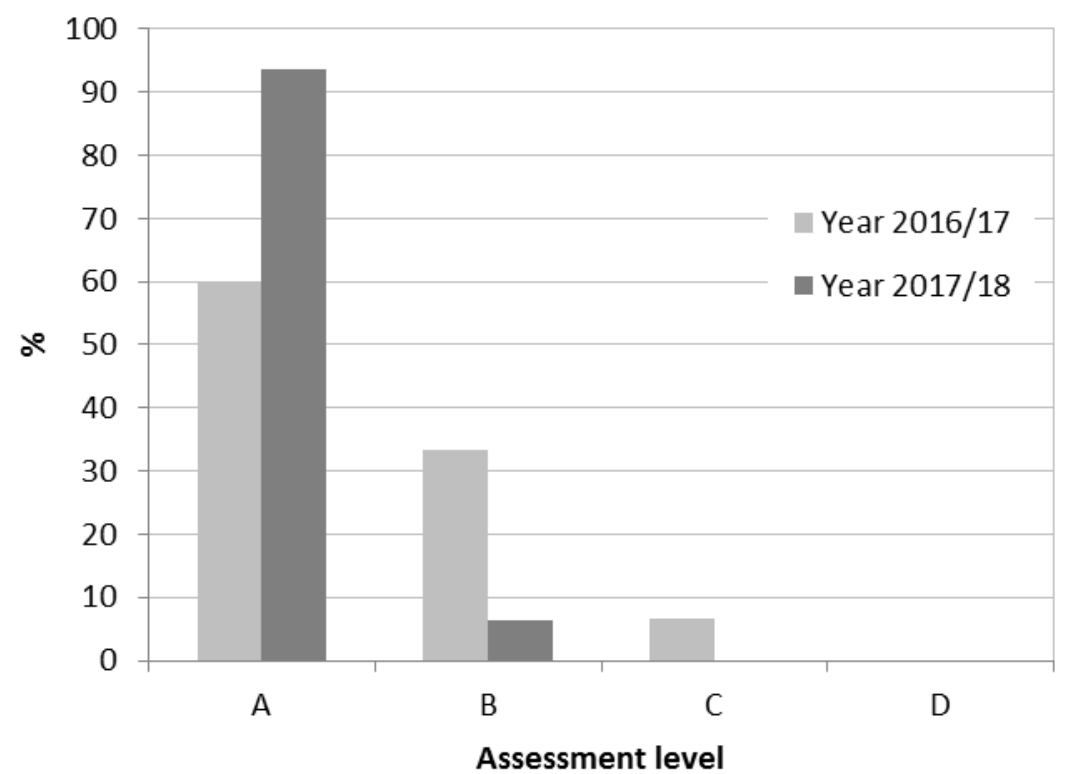

Figure 2. Results of transversal competence evaluation by the rubric.

As it can be seen in the figure, most assessments have been $\mathrm{A}$, specifically $60 \%$ during the year $206 / 17$ and $93,75 \%$ during the year $2017 / 18$. Only one group was rated with a level less than B, 
specifically a $\mathrm{C}$, attributable to a wrong understanding of one of the relevant parts of the project. These transversal competence assessments are consistent with the grades obtained in the Project, previously displayed and analyzed.

\section{CONCLUSIONS}

The main objective of this work was to develop and apply a rubric for the evaluation of the competence "Design and project" in an experimental subject. We have developed a rubric whose subsequent application in two academic years has provided ratings consistent with the results that have been achieved in similar educational contexts. In addition, the assessment of the transversal competence by means of the rubric has also been consistent with the numerical ratings reached.

Lecturers involved in this work have agreed that the main advantages of using the rubric have been the ease and speed of the evaluation process, associated with the clarity of criteria shown through descriptors of the rubric. Furthermore, it has to be highlighted the importance of a continuous review of the rubric to improve the evaluation results.

\section{REFERENCES}

[1] M. Sancho, B. García-Fayos, M. Arnal, "Methodological change in an experimental subject of Chemical Engineering degree: Project learning based on laboratory practice", Proceedings of INTED 2017, pp. 6390-6396, 2017.

[2] K.J. Chua, W.M. Yang, H.L. Leo, "Enhanced and conventional project-based learning in an engineering design module", Int. J. Technol. Des. Educ., vol. 24, pp. 437-458, 2014.

[3] M. Frank, I. Lavy, D. Elata, "Implementing the project-based learning approach in an academic engineering course", Int. J. Technol. Des. Educ., vol. 13, no. 3, pp. 273-288., 2003.

[4] E. Rodríguez-Sandoval, E.M. Vargas-Solanp, J. Luna-Cortés, "Evaluación de la estrategia aprendizaje basado en proyectos", Educ. Educ., vol. 13, no. 1, pp. 13-25, 2010.

[5] A. Jonsson, G. Svingby, "The use of scoring rubrics: Reliability, validity and educational consequences", Educ. Res. Rev., vol. 2, pp. 130-144, 2007.

[6] A. Alcón Latorre, "Rubrics for assessment in higher education", Observa, vol. 10, no. 1, pp. 1-15, 2016.

[7] Y. Malini Reddy, H. Andrade, "A review of rubric use in higher education", Assess. Eval. High. Edu., vol. 35, no. 4, pp. 435-448, 2010.

[8] J.M. Arnal, M. Sancho, B. García-Fayos, A. Santafé-Moros, B. Cuartas-Uribe, "Análisis de los resultados académicos tras la implantación del Aprendizaje Basado en Proyectos en una asignatura experimental", Jornada de Innovación Docente ICE-UPV 2011, Valencia (Spain), 2011. 